\title{
BRAIN RESEARCH
}

Brain Research 860 (2000) 41-52

www.elsevier.com/locate/bres

\section{Research report}

\section{Distribution of the $\mathrm{GABA}_{\mathrm{B}}$ receptor subunit gb2 in rat CNS}

\author{
Janet A. Clark ${ }^{\mathrm{a}, *, 1}$, Éva Mezey ${ }^{\mathrm{b}, 2}$, Alan S. Lam ${ }^{\text {a }}$, Tom I. Bonner ${ }^{\text {a }}$ \\ ${ }^{a}$ Laboratory of Genetics, National Institute of Mental Health, 36 Convent Drive, MSC 4094, Bethesda, MD 20892-4094, USA \\ ${ }^{\mathrm{b}}$ Basic Neuroscience Program, National Institute of Neurological Disorders and Stroke, Bethesda, MD 20892-4094, USA
}

Accepted 21 December 1999

\begin{abstract}
We have identified and isolated human and rat cDNAs for a novel receptor, gb2, with $38 \%$ homology to the GABA $\mathrm{B}$ receptors gb1a and gblb. These receptors comprise a new subfamily of seven transmembrane G protein-coupled receptors (GPCRs) that share structure and sequence similarities with the metabotropic glutamate receptors. In situ hybridization histochemistry using an antisense probe to this novel receptor mRNA shows a distribution in rat CNS nearly identical to that for the gb1 receptor, although some regions showed significant differences. Specifically, message levels for gb2 were virtually absent in the caudate/putamen, and significantly lower in the medial basal hypothalamus, septum and brainstem as compared with gb1 message levels. In contrast to gb1, gb2 mRNA was never detected in white matter suggesting that gb2 message is found exclusively in neurons. Finally, in rat brain regions showing significant overlap of message for $\mathrm{gb} 1$ and $\mathrm{gb} 2$, the transcripts are often found in the same cells. Data from our previous work showing that coexpression of gb2 with gb1 is necessary for expression of a functional receptor together with the detailed anatomical data presented here indicate that native $\mathrm{GABA}_{\mathrm{B}}$ receptors function as heteromeric proteins, the most abundant form being the gb1/gb2 receptor. However, the more limited distribution of gb2 receptor mRNA suggests that there are brain regions where $\mathrm{GABA}_{\mathrm{B}}$ receptors are composed of gb1 and as yet unidentified family members. (C) 2000 Elsevier Science B.V. All rights reserved.
\end{abstract}

Keywords: $\mathrm{GABA}_{\mathrm{B}}$ receptor; Heteromeric; G protein-coupled receptor; Metabotropic receptor; Baclofen; GABA

\section{Introduction}

$\mathrm{GABA}_{\mathrm{B}}$ receptors, originally identified as a distinct subclass of GABA receptors by Bowery et al. [3,4,11] are well established as members of the $G$ protein-coupled receptor (GPCR) super family. They mediate a variety of inhibitory cellular processes through modulation of ion channels and adenylyl cyclase activity [6,17,22]. Kaupmann et al. [14] have described the first primary sequence for a $\mathrm{GABA}_{\mathrm{B}}$ receptor which was isolated from rat brain using expression cloning techniques. The rat $\mathrm{GABA}_{\mathrm{B}}$ receptors identified, rgbla and rgblb, are alternatively spliced variants of the same gene product which differ in their amino terminal sequence and are most closely related to metabotropic glutamate receptors. They exhibit a reduced affinity for $\mathrm{GABA}_{\mathrm{B}}$ receptor compounds as compared with native receptors yet the rank order of potency for

\footnotetext{
* Corresponding author. Fax: +1-301-435-5465; e-mail: janet@codon.nih.gov

${ }^{1}$ Co-first authors.

2 Co-first authors.
}

these compounds is similar to that described in the literature for $\mathrm{GABA}_{B}$ receptors in tissue preparations. Recent work by Couve et al. [10] has shown that recombinant gb1 receptors expressed in heterologous systems do not reach the cell surface and are trapped in the endoplasmic reticulum. These data suggest that the gb1 receptors require additional information for functional targeting to the plasma membrane that appears to be missing in the cells used to study receptor function thus far. Until recently there had been no meaningful study of the function of these receptors. We and others have recently reported that coexpression of gb1a or gb1b with a related protein, $\mathrm{gb} 2$, in various heterologous expression systems results in the expression of functional $\mathrm{GABA}_{\mathrm{B}}$ receptors $[12,15,19,23,29]$. The results of these studies suggest that the native $\mathrm{GABA}_{\mathrm{B}}$ receptor may be a heterodimer of gb1 and gb2 subunits.

Here we describe the isolation of human and rat cDNAs for the gb2 $\mathrm{GABA}_{\mathrm{B}}$ receptor subunit and the CNS distribution of gb2 mRNA in the rat. This is only the second $\mathrm{GABA}_{\mathrm{B}}$ receptor primary sequence to be identified. In situ hybridization histochemistry revealed that $\mathrm{gb} 2$ and $\mathrm{gb} 1$ mRNA exhibit overlapping expression patterns in many rat 
brain regions with transcripts for both receptors found in the same cells in a vast majority of cases. The colocalization data are supportive of our previous studies showing that coexpression of gb2 with gb1 in heterologous expression systems is necessary to observe $\mathrm{GABA}_{\mathrm{B}}$ receptor function [23]. In addition, rgb2 mRNA exhibits a more discrete expression pattern in some rat brain regions than rgb1 and appears to be absent from white matter suggesting that it is predominantly localized to neurons. If functional $\mathrm{GABA}_{\mathrm{B}}$ receptors are composed of heteromers then the finding that rgb1 message is abundant in many brain regions and in white matter where rgb2 is barely detectable suggests that there may be additional, as yet unidentified $\mathrm{GABA}_{\mathrm{B}}$ receptors.

\section{Materials and methods}

\subsection{Cloning of $h g b 2$}

A tblastn search of the Genbank EST database using the amino acid sequence of the rat gb1 receptor as query detected three ESTs, R76139, R80448, and Z43654, which showed distant homology to transmembrane domains 5-7 and another EST, T07261, which showed similarity to transmembrane domains 1-3. Primers designed from these sequences (JC136 gcgggatccCTTCGGCACGAAT ACCAGGCAGAGGGT for 5' extension; JC137 ccggaattcCAGAAGCTCATAAAGATGTCGAGTCC and JC135 ccggaattcTTCTTAGCTTTGGGAGACCCGCA ACGT for $3^{\prime}$ extension) were used with the Clontech AP1 primer (Clontech; Palo Alto, CA) to do 5' and $3^{\prime}$ RACE using Clontech Marathon-Ready human brain cDNA as template and touchdown PCR conditions $\left(94^{\circ} \mathrm{C}, 30 \mathrm{~s}\right.$ and $72^{\circ} \mathrm{C}, 4 \mathrm{~min}$ for five cycles; $94^{\circ} \mathrm{C}, 30 \mathrm{~s}$ and $70^{\circ} \mathrm{C}, 4 \mathrm{~min}$ for five cycles; $94^{\circ} \mathrm{C}, 30 \mathrm{~s}$ and $68^{\circ} \mathrm{C}, 4 \mathrm{~min}$ for 20 cycles). JC135 and JC136 primers were derived from the transmembrane domains 5-7 ESTs while JC137 was derived from T07621. JC136 and JC137 primers were used together to generate a product of 722 bases which when sequenced confirmed that the ESTs were derived from the same mRNA. 3' products from RACE with JC135 and JC137 were reamplified with the Clontech AP2 primer yielding two products of 1.2 and $1.7 \mathrm{~kb}$ in size but lacking a poly(A) signal. A tblastn search of the Genbank EST database with the $3^{\prime}$ sequences detected an EST, AA323988, which overlapped with the query sequence and extended the sequence through an A-rich region. gb2-15 (AGCACTAGAACTCCAGCTGGAAGTCA) was designed based on EST AA323988 and used in a $3^{\prime}$ RACE reaction as described above to yield a $2.3-\mathrm{kb}$ band that when sequenced was shown to include a poly(A) signal. 5' RACE with JC136 yielded a 0.88-kb NotI/BamHI fragment which when sequenced showed weak amino acid homology to rgb1. JC153 (GCCTACGATGGCATCTGGGTCATCGC) was designed based on the JC136 5' RACE product sequence and paired with JC136 to yield a 1.1-kb fragment. Further $5^{\prime}$ extensions were obtained by using Clontech Advantage-GC PCR ( $1 \mu \mathrm{l}$ GC-melt per $50 \mu \mathrm{l}$ reaction, PCR conditions: $94^{\circ} \mathrm{C}, 15 \mathrm{~s}$ and $68^{\circ} \mathrm{C}, 3.5 \mathrm{~min}$ for 30 cycles) and nested primers JC152 (CAGATTCCAGCCTTGGAGGGACTCTGC) followed by JC186 (TGCATCGTAGAAGGCTTTCAACCCTTTTGC) and adapter primers AP1 followed by AP2.

pcDhgb2I was generated by subcloning a NaeI/XhoI fragment from a JC153/JC165 (JC165: AATAAGGCTCGAGGTCAGGTGCCAA) $2.2 \mathrm{~kb}$ PCR product and an EcoRI/NaeI fragment from a JC171/JC154 (JC171: CAGCAGCCCGCCGCTCTCCATCAT; JC154: gcgcgtaatacgactcactatagggGTAGTTGAAGTCCTGGATCCG) $1.0 \mathrm{~kb}$ PCR product into EcoRI/XhoI digested pcDNA1/amp (Invitrogen; Carlsbad, CA). The expression construct pcDhgb2II was constructed by subcloning a NotI/XmnI 5' RACE fragment obtained with AP2/JC186 into a NotI/XmnI digested pcDhgb2I. pcD3.1hgb2 was made by subcloning an EcoRI/XbaI fragment from pcDhgb2II into EcoRI/XbaI digested pcDNA3.1 (Invitrogen).

The JC135 and JC137 3' RACE reactions yielded a closely spaced pair of bands. When individual clones were sequenced they appeared to represent alternatively spliced $3^{\prime}$ ends of the hgb2 cDNA (Genbank accession numbers AF056085, AF095723 and AF095724). The 1.7-kb JC137 clone (hgb2 (c), Fig. 2) lacked an exon corresponding to bases 3239-3319. The JC153/JC165 2.2 kb clone (hgb2 (b), Fig. 2) that was used to make the expression construct pcDhgb2II lacked an exon corresponding to bases 31613238. The relative intensities of the PCR bands indicated that the two smaller gb2 receptor variants combined are several-fold less abundant than the longer form.

\subsection{Cloning of rgb2}

rgb2 (Genbank accession AF058795) was obtained by screening pools of clones from a rat cortex cDNA library made in the Okayama-Berg vector pCD.1 [2] using Southern blot analyses. DNA was prepared from each of 49 pools representing an average of $5 \times 10^{5}$ clones per pool and digested with $X h o I$ to release the inserts from the vector DNA. Five microgram of XhoI digested pool DNA was run on a $0.8 \%$ agarose gel and transferred to a nitrocellulose supported membrane (BA-S 85, Schleicher \& Schuell; Keene, NH) using a TurboBlotter (Schleicher \& Schuell). Nitrocellulose membranes were hybridized with a ${ }^{32}$ P-labeled random primed (Boerhinger Mannheim; Indianapolis, IN) hgb2 JC137/JC136 PCR fragment in $3 \times$ Denhardt's and $3 \times \mathrm{SSC}$ at $60^{\circ} \mathrm{C}$. Hybridization was followed by two 15 -min washes in $3 \times \mathrm{SSC}$ at $60^{\circ} \mathrm{C}$. Blots were imaged on the Fujix PhosphorImaging system (Fuji; Japan). Bacteria from two pools were each used to make 22 subpools. DNA was prepared from these pools and analyzed as above. Two positive pools (10I and 37O) of 
3000 colonies each were screened by colony hybridization following standard protocols [28]. Two similar clones were isolated from this screen the longest of which $(5200 \mathrm{~kb}$ clone 37094a) was sequenced and found to lack a start site. RACE was performed using the high GC conditions described above with nested primers JC190 (CGCTGGTGCAGGGATCATTGGAGAA) and JC191 (CATATTCTGGTCAAACTGGCCAAGG) paired with AP1 followed by AP2 using Clontech Marathon-Ready rat brain cDNA as template to yield the $5^{\prime}$ end of the $\mathrm{rgb} 2$ receptor. A XhoI/BglII fragment from the $5^{\prime}$ RACE of rgb2 and a $B g l$ II fragment from $37094 a$ were subcloned into XhoI/BamHI digested pBSSKII $(-)$. Restriction enzyme mapping with XhoI and BamHI established the correct orientation of the $B g l$ II fragment. pcD3.1rgb2 was made by subcloning a $K p n \mathrm{I} / \mathrm{BamHI}$ fragment of the pBSSKII ( - ) plasmid with a BamHI/XbaI fragment from 37094a into KpnI/XbaI digested pcDNA3.1.

\subsection{Cloning of rgblb and rgbla}

rgblb was obtained by amplification of Clontech rat brain Marathon-Ready cDNA with JC140 (ccggaattcccaccATGGGCCCGGGGGGACCCTGTACC) and JC141 CTAGTCTAGATCACTTGTAAAGCAAATGTACTCGAT). pBSrgb1b was made by ligation of an EcoRI/XbaI fragment of rgblb into EcoRI/XbaI prepared pBSSKII $(-)$. pcDrgb1b was constructed by subcloning an EcoRI/NotI fragment from pBSrgblb into EcoRI/Not I prepared pcDNA1/amp (Invitrogen). rgbla $5^{\prime}$ sequence was obtained by $5^{\prime}$ RACE with AP1 or 2 paired with JC144 (GAGTAGTTCGTACAAGTACTTGGTGGC) using Clontech rat brain Marathon-Ready cDNA as template. A rgbla 5' fragment for vector construction was generated by amplification of the JC144 RACE product with JC139 (ccggaattccaccATGCTGCTGCTGCTGCTGGTGCCTCTC) and JC144. pBSrgb1a was made by ligation of an EcoRI/HpaI fragment from the JC139/JC144 PCR product into EcoRI/HpaI digested pBSrgb1b. pcDrgbla was constructed by subcloning an EcoRI/BstEII fragment from the pBSrgb1a into EcoRI/BstEII digested pcDrgb1b. An EcoRI/Not I fragment from pcDrgbla was subcloned into pcDNA3.1 (Invitrogen) to make pcD3.1rgb1a.

\subsection{Northern analysis}

Clontech multiple human tissue northerns were hybridized with the $0.88 \mathrm{~kb} \operatorname{Not} \mathrm{I} / \operatorname{BamHI}$ fragment (bases $732-1613$ of hgb2) at $42^{\circ} \mathrm{C}$ in $5 \times$ SSPE, $10 \times$ Denhardt's, $50 \%$ formamide, $2 \% \mathrm{SDS}, 100 \mu \mathrm{g} / \mathrm{ml}$ denatured salmon sperm DNA. Following hybridization blots were washed three times for $10 \mathrm{~min}$ each in $0.2 \times \mathrm{SSPE}, 1 \% \mathrm{SDS}$ at $60^{\circ} \mathrm{C}$. Blots were imaged on the Fujix PhosphorImaging system (Fuji).

\subsection{In situ hybridization histochemistry}

Preparation of rat brain sections and probes as well as hybridization of rat brain slices were performed as described previously [7,18] (http://intramural.nimh. nih.gov/lcmr/snge/Protocol.html). Sections were hybridized with ${ }^{35} \mathrm{~S}$-UTP-labeled antisense and sense riboprobes directed against rgb2 or rgb1 mRNA. Probes were generated by amplification of rgb2 with JC216 paired with JC217 or with JC218 paired with JC219 (JC216: cgcgcaattaaccctcactaaaggACAACAGCAAACGTTCAGGC; JC217: gcgcgtaatacgactcactatagggCATGCCTATGATGGTGAG;

JC218: cgcgcaattaaccetcactaaaggCTGAGGACAAAC CCTGACGC; JC219: gcgcgtaatacgactcactatagggGATGTCTTCTATGGGGTC) or by amplification of rgb1 with JC160 paired with JC161 (JC160:cgcgcaattaaccetcactaaaggAAGCTTATCCACCACGAC; JC161:gcgcgtaatacgactcac tatagggAGCTGGATCCGAGAAGAA) and labeled as described previously.

\subsection{Simultaneous detection of gb2 and gbl transcripts by} in situ hybridization histochemistry

For simultaneous detection of gb1 and gb2 transcripts procedures were the same as described above except that rgb1 probes were labeled with digoxigenin-UTP. Brain slices were simultaneously hybridized with probes to both gb1 and gb2 receptors and digoxigenin-labeled gb1 receptor message was detected using a peroxidase-conjugated antibody amplification scheme involving biotinyl tyramide (TSA amplification procedure, NEN; Boston, MA) and subsequent detection with streptavidin-conjugated CY3. Detection of the radiolabeled rgb2 probe was performed after detection of the digoxigenin-labeled rgb1 probe on the same brain slices.

\section{Results}

\section{1. hgb2 and rgb2 amino acid sequences}

Through EST database searches, polymerase chain reaction, and library screening as described in Section 2 we have identified and isolated human and rat homologues of a novel receptor, hgb2 and rgb2, with homology to the $\mathrm{GABA}_{\mathrm{B}}$ receptors, rgbla and rgb1b, identified by Kaupmann et al. [14]. Fig. 1 shows a schematic of the hgb2 and rgb2 receptor nucleotide sequences denoting the placement of oligonucleotide primers and restriction enzyme sites used to generate each of these constructs and the expression plasmids. hgb2 receptor fragments were amplified from human brain cDNA while rgb2 was isolated from a rat cortex cDNA library followed by amplification of rat brain cDNA to obtain the $5^{\prime}$ end of the receptor including 
hb 2

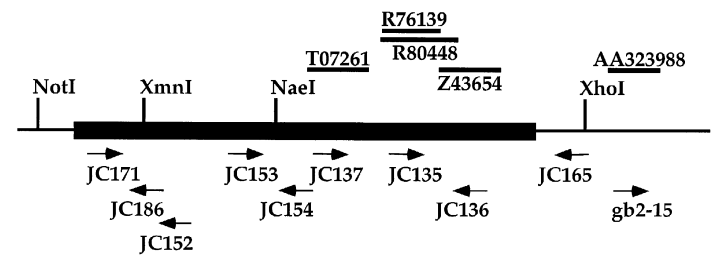

$\operatorname{rgb2}$

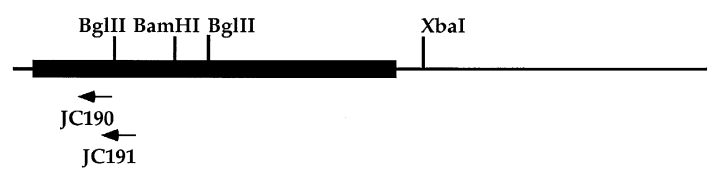

Fig. 1. Schematic diagrams of hgb2, and rgb2 sequences showing the relative location of ESTs, oligonucleotide primers and restriction enzyme sites used in constructing the cDNAs. Constructs were generated as described in Section 2. Thin bars represent noncoding regions of the cDNAs; thick bars represent the coding regions. Left facing arrows represent sense primers; right facing arrows represent antisense primers.

the start site. The resulting 5786 base pair sequence generated for hgb2 includes an open reading frame of 2826 bases. Some of the ESTs corresponding to hgb2 had previously been mapped by radiation hybrid analysis to the D9S287-D9S176 region of chromosome 9q (http:// www.ncbi.nlm.nih.gov /genemap98/map.cgi?MAP = G3$\& \mathrm{BIN}=323 \&$ MARK $=$ SHGC-32035). The combined $5^{\prime}$ RACE product and insert for rgb2 spans 5459 base pairs and includes an open reading frame of 2823 bases. The cDNA sequences for hgb2 and rgb2 predict proteins of 942 and 941 amino acids, respectively, with relative molecular mass of $104 \mathrm{kD}$.

Sequence similarity and hydropathy profiles [20] of the predicted proteins demonstrate that they share structural features with the gb1 receptors [14], the parathyroid cell calcium-sensing receptor, and the family of metabotropic glutamate receptors [26]. Significant features in the hgb2 and $\mathrm{rgb} 2$ sequences include seven putative transmembrane regions, a large extracellular amino terminus of 476 residues, and four potential sites for $\mathrm{N}$-linked glycosylation (Fig. 2). Potential signal peptide cleavage sites were identified in the gb2 receptor sequences (Fig. 2) using a neural network method for identification of signal peptides and prediction of their cleavage sites [9,24] (http:// www.cbs.dtu.dk/services/SignalP/). Comparison of the amino acid sequences for hgb2 and rgb2 with that for

Fig. 2. Alignment of human gb2, rat gb2, rat gb1a and rat gb1b receptor amino acid sequences. C-terminal alternative splice variants of human $\mathrm{gb} 2$ are designated $\mathrm{a}, \mathrm{b}$, and $\mathrm{c}$. Dots indicate residues identical in all receptors. Hydrophobic domains are denoted by bars and labeled with the transmembrane domain (TM) number. Proposed signal peptide cleavage sites [24] (http://www.cbs.dtu.dk/services/SignalP/) for human and rat $\mathrm{gb} 2$ are denoted with an X. Potential N-linked glycosylation sites are designated by an asterisk over the appropriate residues. hgb2 MASPRSSGQPGPPPPPPPPARLLLLLLLPLLLrgb2 MASPPSSGQPR-PPPPPPPPARLLLPLLLSLLL rgb1a
rgb1b MGPGGCTPVGWPLPLLLVMAGGVAPVWNATSECQIIHPPWEGI

hab 2

hgb2 $r g b 2$
$r g b 1 a$

hgb2

rgb2

rgb1 a RCVRICSKSYLTLENGKVFLTGGDLPALDGARVEFRCDPDFHLVGSSRSVCSQ
rgb1b $\mathbf{x}$

hgb2 PLAPG-AWGWARGAPRPPPSSPPLS IMGLMPLTKEVAKGSIGRGVLPAVELAI rgb2 WLAPG-AWGWTRGAPRPPPSSPPLS IMGLMPLTKEVAKGSIGRGVLPAVELAI rgb1b HS-PHLPRPHPRVPPHPSSERRAVY IGALFPMS-GGWPG--GQACQPAVEMAL $\begin{array}{lc} & \star \\ \text { hgb2 } & \text { EQIRN-ESLLRPYFLDLRLYDTECDNAKGLKAFYDAIKYGPNHLMVFGGVPS } \\ \text { rgb2 } & \text { EQIRN-ESLLRPYFLLRLYDTECDNAKGLKAFYDAIKYGPNHLMVFGGVCPS }\end{array}$ rgb1 EDVNSRRDILPDYELKLIHHDSKCDPGQATKYLYELLYNDPIKIILMPG-CSS

hgb2 VTSIIAESLQGWNLVQLSFAATTPVLADKKKYPYYFRTVPSDNAVNPAILKLL rgb2 VTSIIAESLQGWNLVQLSFAATTPVLADKKKYPYFFRTVPSDNAVNPAILKLL rgb1 VSTLVAEAARMWNLIVLSYGSSSPALSNRQRFPTFFRTHPSATLHNPTRVKLF

hgb2 KHYQWKRVGTLTQDVQRFSEVRNDLTGVLYGEDIEISDTESFSNDPCTSVKKL rgb2 2 KHFRWRRVGTLTQDCQRFSEVRNDLTGVLYGEDIEISDTESFSNDPCTSVKKL rgb1 EKWGWKKIATIQQTTEVFTSTLDDLEERVKEAGIEITFRQSFFSDPAVPVKNL

hgb2 KGNDVRIILGQFDQNMAAKVFCCAYEENMYGSKYQWIIPGWYELSWWEQVHTE $r g b 2$ KGNDVRI ILGQFDQNMAAKVFCCAFEESMFGSKYQWIIPGWYEPAWWEQVHVE KRQDARIIVGLFYETEARKVFCEVYKERLFGKKYVWFLIGWYADNWFK---TY * $\cdots \cdots \cdot \cdots \cdot \cdot \cdots \cdot \cdots \cdot$

hgb2 ANSSRCLRKNLLAAMEGYIGVDFEPLSSKQIKTISGKTPQQY-EREYNN-KRS rgb2 ANSSRCLRRSLLAAMEGYIGVDFEPLSSKOIKTISGKTPQQF-EREYNS-KRS rgb1 DPSINCTVEEMTEAVEGHITTEIVMLNPANTRSISNMTSQEFVEKLTKRLRRH

$\begin{array}{ccccccc}\bullet & \bullet & \bullet & \cdots & \bullet & \vdots & \cdots\end{array}$ rgb2 GVGPSKFH-G-YAYDGIWVIAKTLQRAMETLHASSRHQRIQDFNYTDHTLGKI rgb1 PEETGGFQEAPLAYDAIWALALALNKTSGGGGRSGV-RLEDFNYNNQTITDQ GGFEAPLYDAIWALALALNKTSGGGGRSGV--RLEDFNYNNQTITDQ

hgb2 ILNAMNETNFFGVTGQVVFR-NGERMGTIKFTQFQDSREVKVGEYNAVADTLE rgb2 ILNAMNETNFFGVTGQVVFR-NGERMGTIKFTOFQDSREVKVGEYNAVADTLE rgb1 IYRAMNSSSFEGVSGHVVFDASGSRMAWTLIEQLQGGSYKKIGYYDSTKDDL$\cdots \cdots \cdots \cdots$

hgb2 IINDTIRFQGSEPPKDKTIILEQLRKISLPLYSILSALTILGMIMASAFLFFN $r g b 2$ IINDTIRFQGSEPPKDKTIILEQLRKISLPLYSILSALTILGMIMASAFLFFN rgb1 SWSKTDKWIGGSPPADQTLVIKTFRFLSQKLFISVSVLSSLGIVLAVVCLSFN TM2

hgb2 IKNRNQKLIKMSSPYMNNLIILGGMLSYASIFLFGLDGSFVSEKTFETLCTVR rgb2 IKNRNOKLIKMSSPYMNNLIILGGMLSYASIFLFGLDGSFVSEKTFETLCTVR rgb1 IYNSHVRYIQNSQPNLNNLTAVGCSLALAAVFPLGLDGYHIGRSQFPFVCQAR - • • . . • • • • ... $\begin{array}{ll}\text { hgb2 } & \text { TWILTVGYTTAFGAMFAKTWRVHAIF--KNVKM-KKKIIKDQKLLVIVGGMLL } \\ \text { rgbb2 } & \text { TWILTVGYTAFGAMFAKTWRVHAIF--KNVKM-KKKIIKDQKLVIVGGMLL }\end{array}$

rgb1 LWLLGLGFSLGYGSMFTKIWWVHTVFTKKEEKKEWRKTLEPWKLYATVGLLVG

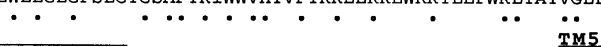

hgb2 $\overline{\text { IDLCILICWQAVDPLRRTVEKYSMEPDPAGRDISIRPLLEHCENTHMTIWLGI }}$

rgb2 IDLCILICWQAVDPLRRTVERYSMEPDPAGRDISIRPLLEHCENTHMTIWLGI

rgb1 MDVLTLAIWQIVDPLHRTIETFAKEEPKEDIDVSILPQLEHCSSKKMNTWLGI

hgb2 $\frac{\bullet \cdots \cdots}{\text { VYAYKGLLMLFGCFLAWETRNVSIPALNDSKYIMGSVYNVGIMCIIGAAVSFL }}$

rgb2 VYAYKGLLMLFGCFLAWETRNVSIPALNDSKYIGMSVYNVGIMCIIGAAVSFL

rgb1 FYGYKGLLLLLGIFLAYETKSVSTEKINDHRAVGMAIYNVAVLCLITAPVTMI $\cdots$

hgb2 TRDQPNVQFCIVALVIIFCSTITLCLVFVPKLITL--RTNPDAATQN-RRF-Q rgb2 TRDQPNVQFCIVALVIIFCSTITLCLVFVPKLITL--RTNPDAATQN-RRF- $Q$ rgb1 LSSQQDAAFAFASLAIVFSSYITLVVLFVPKMRRLITRGEWQSETQDTMKTGS

hgb2 FTQNQKKEDSK-TSTSVTSUNQASTSRLEGLQSENHRLRMKITELDKDLEEVT rgb2 FTQNQKKEDSK-TSTSVTSVNQASTSRLEGLQSENHRLRMKITELDKDLEEVT rgb1 STNNNEEEKSRLLEKENRELEKIIAEKEERV-SELRHQLQSRQQLRSRRHPPT $\begin{array}{ll}\mathrm{hgb2} & \text { MQLQDTPEKTTYIKQNHYQELNDILNLGNFTESTDGGKAILKNHLDQNPQLQW } \\ \mathbf{r g b 2} & \text { MQLQDTPEKTTYIKQNHYQELNDILSLGNFTESTDGGKAILKNHLDQNPQLQW }\end{array}$ $\begin{array}{ll}r g b 2 & \text { MQLQDTPEKTTYIKQNHYQELNDLSLGNFT } \\ \text { rgb1 } & \text { PPDPGGLPRGPEPPDRLSCDGSRVHLLYK }\end{array}$

hgb2 (a) NTTEPSRTCKDPIEDINSPEHIQRRLSLQLPILHHAYLPSIGGVDASCVS hgb2 (b) NTTEPSRTCKDPIEDINSPEHIQRRLSLQLPILHH-hgb2 (c) NTTEPSRTCKDPIEDINSPEHIQRRLSLQLPILHHAYLPSIGGVDASCVS
rgb2

hgb2 (a) PCVSPTASPRHRHVPPSFRVMVSGL

hgb2 (b) --

hgb2 (c) PCVSPTASPRHRTTLGRGVCCRNTVGSGCGEAGHHGWPLRTTRMALRWTG $r g b 2$ PCVSPTASPRHRHVPPSFRVMVSGL

hgb2 (c) RGRGRLGT 
rgb1a and rgb1b (Fig. 2) shows $28 \%$ amino acid identity which rises to $40 \%$ when conservative amino acid substitutions are taken into account. Homology between the gb2 and gb1 receptors is not limited to the hydrophobic regions but instead spans the entire protein. As was the case with gb1, gb2 shares sequence homology with metabotropic glutamate and the calcium-sensing receptors [14].

\section{2. rgb2 expression in rat CNS}

Analyses of Northern blots of human mRNA from several brain regions and peripheral tissues with a probe directed against the hgb2 receptor reveals a single mRNA species of $6.2 \mathrm{~kb}$ (Fig. 3). hgb2 receptor mRNA is expressed in all of the brain areas tested although the level of expression seems to vary significantly with the highest in the cortex and thalamus and the lowest in the corpus callosum, caudate nucleus, and medulla. In addition, a weak $6.2 \mathrm{~kb}$ band is detected in spinal cord mRNA. No hgb2 receptor mRNA is detected by Northern analysis in any of the peripheral tissues examined with the exception of heart where a weak band is observed.

In situ hybridization histochemistry was carried out using sense and antisense probes directed against both the rgb2 and rgb1 receptors for comparison as described in Section 2. The rgb1 receptor probe is directed against a region common to both the rgbla and rgblb receptors (Section 2), therefore, both rgbla and rgblb mRNAs are recognized by this probe. Both rgb2 and $\mathrm{rgb} 1$ receptor mRNAs are heterogeneously expressed in the rat brain with many regions showing an overlap for the two receptor transcripts.
Gb2 and gb1 receptor mRNAs are equally abundant in the cortex, thalamus, medial and lateral geniculate bodies, habenula, and cerebellum (Fig. 4). Unlike gb1 receptor message, which is very abundant and heterogeneously expressed throughout the rat CNS [14], the distribution of the gb2 receptor message is somewhat more discrete. There are several brain regions that show major differences in the levels of mRNA for the two receptors. Gb2 receptor message is virtually absent from the caudate/ putamen (Figs. 4B-D and 5C) and its levels are significantly lower than that of the gb1 receptor mRNA in the septum, the preoptic area and the hypothalamus (Figs. $4 \mathrm{C}-\mathrm{F}$ and $5 \mathrm{~B}-\mathrm{E})$. Whereas gb1 receptor message is homogeneously expressed throughout the regions in which it is found, this is not always the case for gb2 receptor message. Despite the relatively low levels of $\mathrm{gb} 2$ receptor mRNA in the hypothalamus, gb2 message is abundantly expressed in the magnocellular neurons of the hypothalamic paraventricular and supraoptic nuclei (Fig. 4F and Fig. $5 \mathrm{E})$ and expressed at medium to high levels in the dorsomedial hypothalamic nucleus and the suprachiasmatic nuclei (Fig. 4E, and Fig. 5E). Gb2 receptor message is expressed at relatively low levels in catecholaminergic brain areas such as the substantia nigra and locus coeruleus (Fig. $4 \mathrm{H}$ and $\mathrm{J}$, respectively), areas where gb1 receptor message is abundant (data not shown). Message for both receptors are detected in high levels in the hippocampus, however, a significant difference in the expression patterns for these two receptor mRNAs in the hippocampus was observed. Gb2 receptor message shows a graded pattern of expression in the hippocampus with relatively low levels in the CA1 area, somewhat higher levels in CA2, and very high levels in CA3 and the dentate gyrus (Fig. 4G). Gb1 receptor message is abundantly and homogeneously ex-

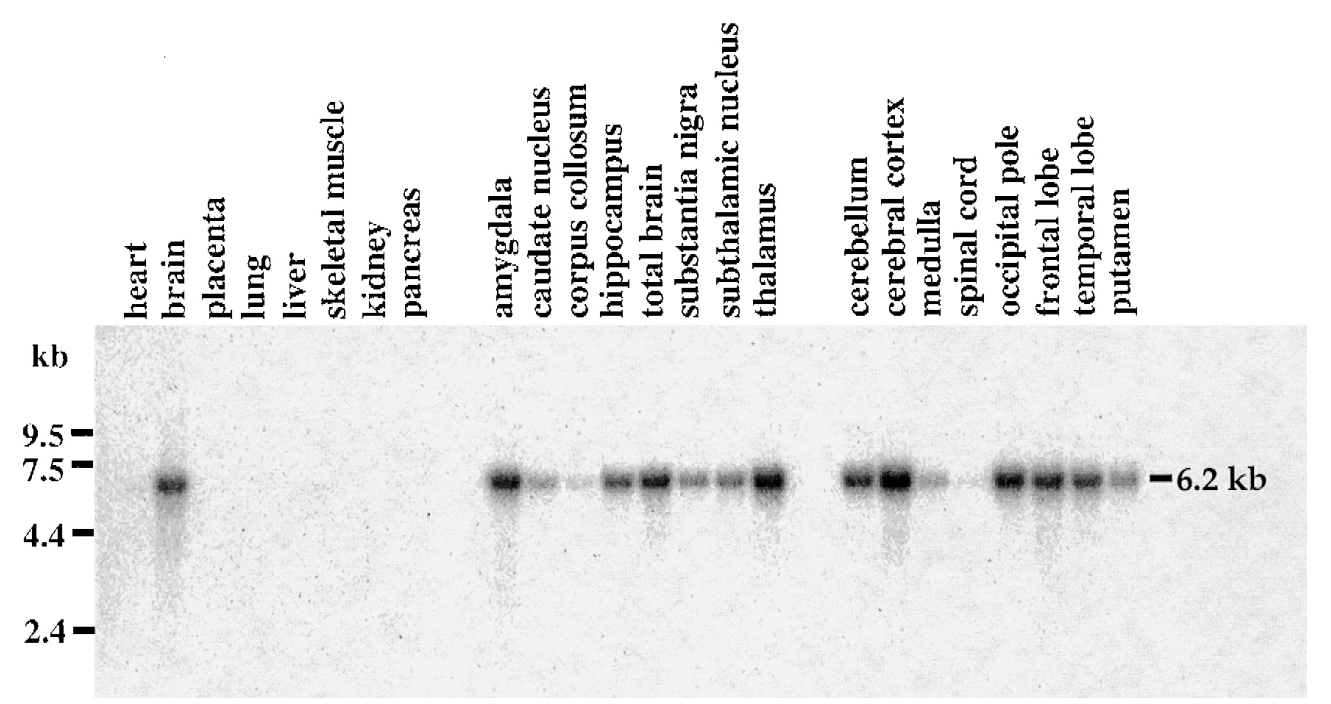

Fig. 3. hgb2 mRNA expression in human CNS and peripheral tissues as determined by Northern blot analysis. Clontech multiple human tissue Northerns were hybridized with a probe directed against the hgb2 receptor as described in Section 2. Note the weak band present in heart and spinal cord human mRNA. 

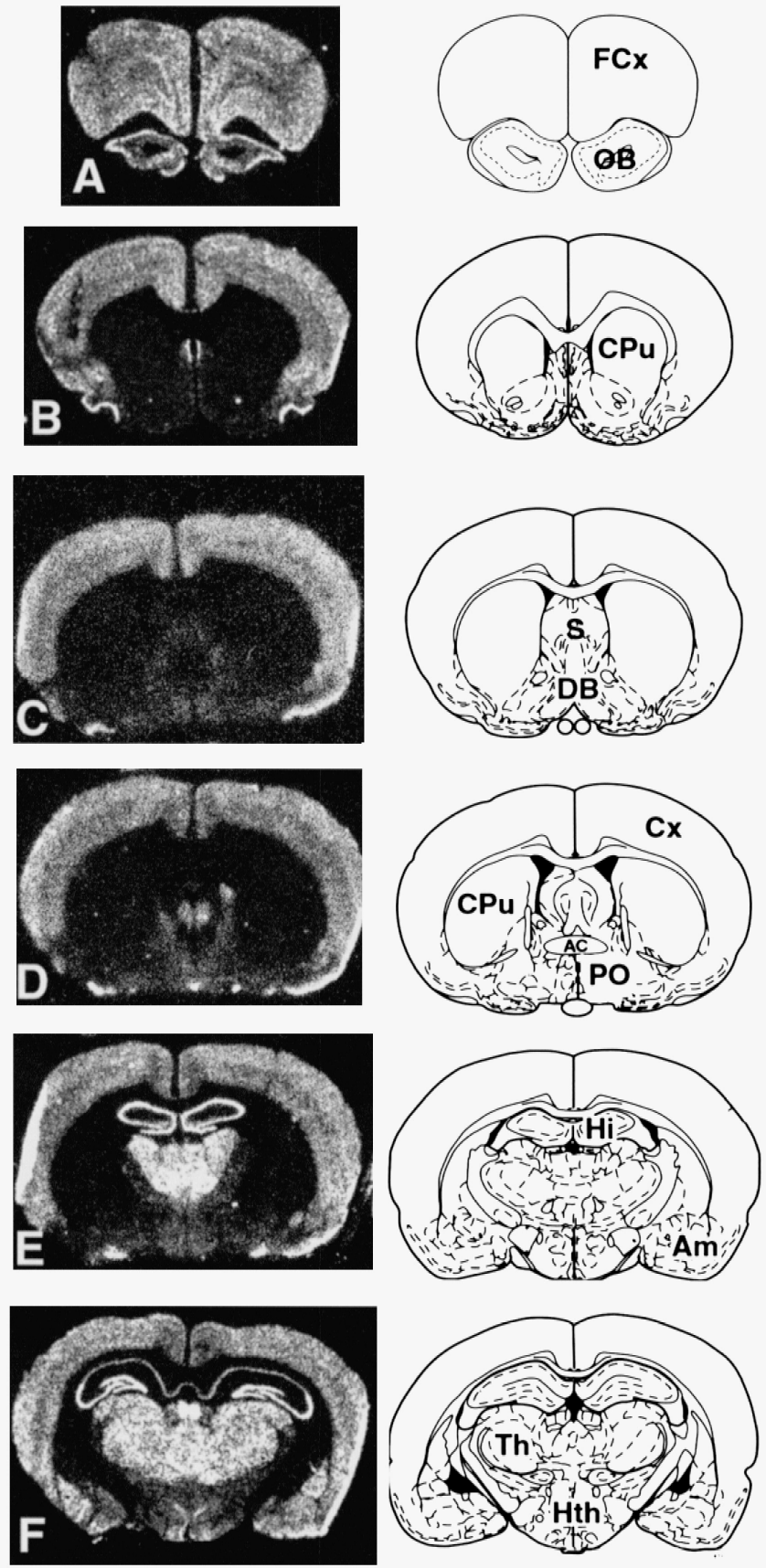

Fig. 4. Distribution of the gb2 receptor mRNA in coronal sections of rat brain by in situ hybridization histochemistry. (A-M) Autoradiographic images were scanned from X-ray film opposed to the microscope slides after hybridization and exposed for 5 days. Scanned images were saved in Adobe Photoshop 5 and combined with drawings from Paxinos and Watson's Atlas [25] showing the corresponding levels. Abbreviations: AC $=$ accumben nucleus; $\mathrm{Am}=$ amygdala; $\mathrm{AP}=$ area postrema; $\mathrm{CA} 1, \mathrm{CA} 2, \mathrm{CA} 3=$ hippocampal subdivisions; $\mathrm{CB}=$ cerebellum; $\mathrm{Cpu}=\mathrm{caudate} / \mathrm{putamen}$; $\mathrm{Cx}=$ cortex; $\mathrm{DB}=$ diagonal band of Broca; $\mathrm{DR}=$ dorsal raphe; $\mathrm{FCx}=$ frontal cortex; $\mathrm{Hi}=$ hippocampus; $\mathrm{Hth}=$ hypothalamus; $\mathrm{IC}=$ inferior colliculus; $\mathrm{IO}=$ inferior olive; $\mathrm{MG}=$ medial geniculate nucleus; $\mathrm{OB}=$ olfactory bulb; $\mathrm{P}=$ pons; $\mathrm{PO}=$ preoptic hypothalamus; $\mathrm{S}=$ septum; $\mathrm{SN}=$ substantia nigra; $\mathrm{Th}=$ thalamus.

pressed throughout all areas of the hippocampus (data not shown).

In the brainstem, gb2 receptor mRNA is expressed at equally high levels in the cerebellum (Purkinje and granule cells) and in a few restricted nuclei including the inferior olive, lateral reticular formation, solitary tract nucleus, and the dorsal parabrachial nucleus (Fig. 4J-M). However, gb1
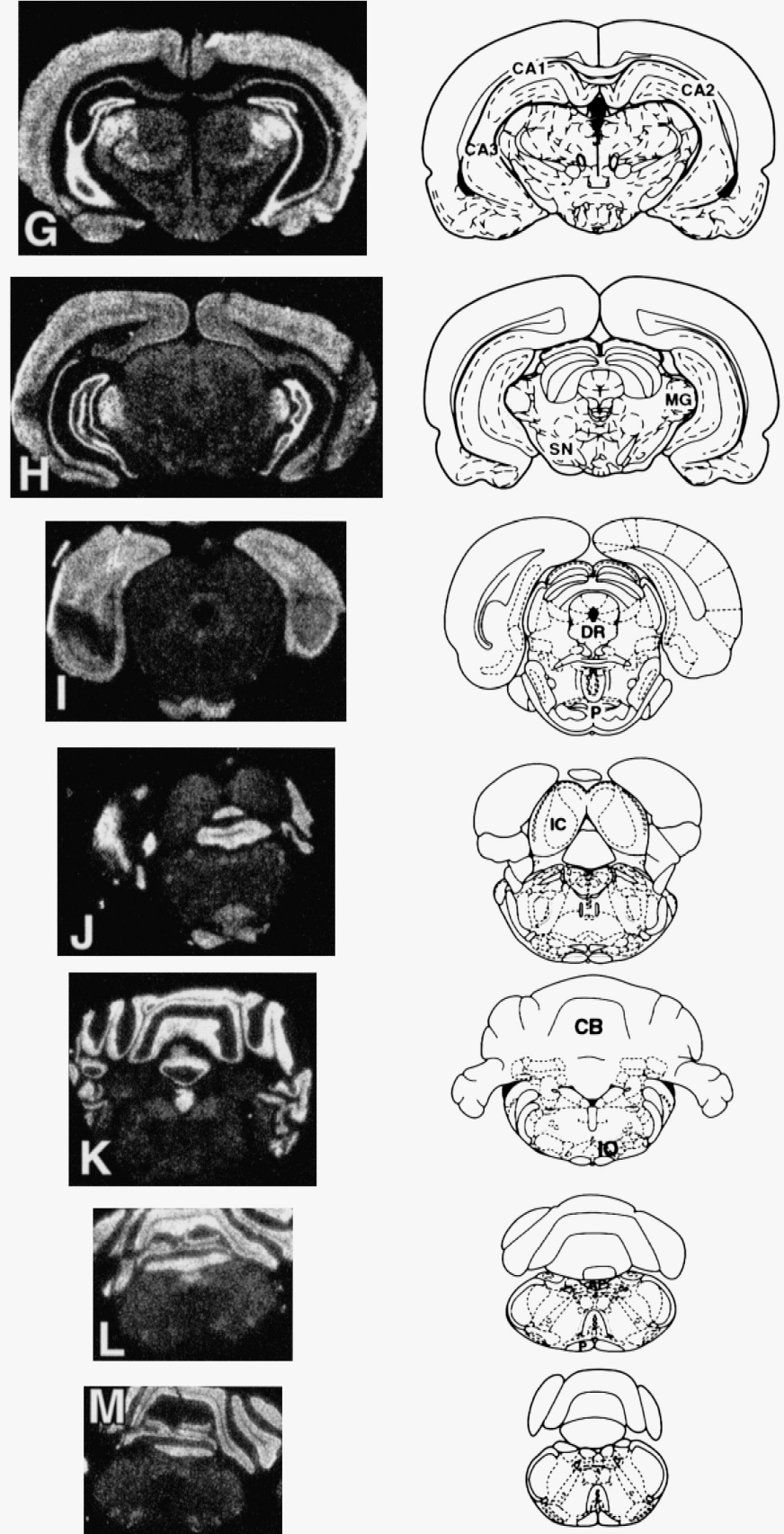

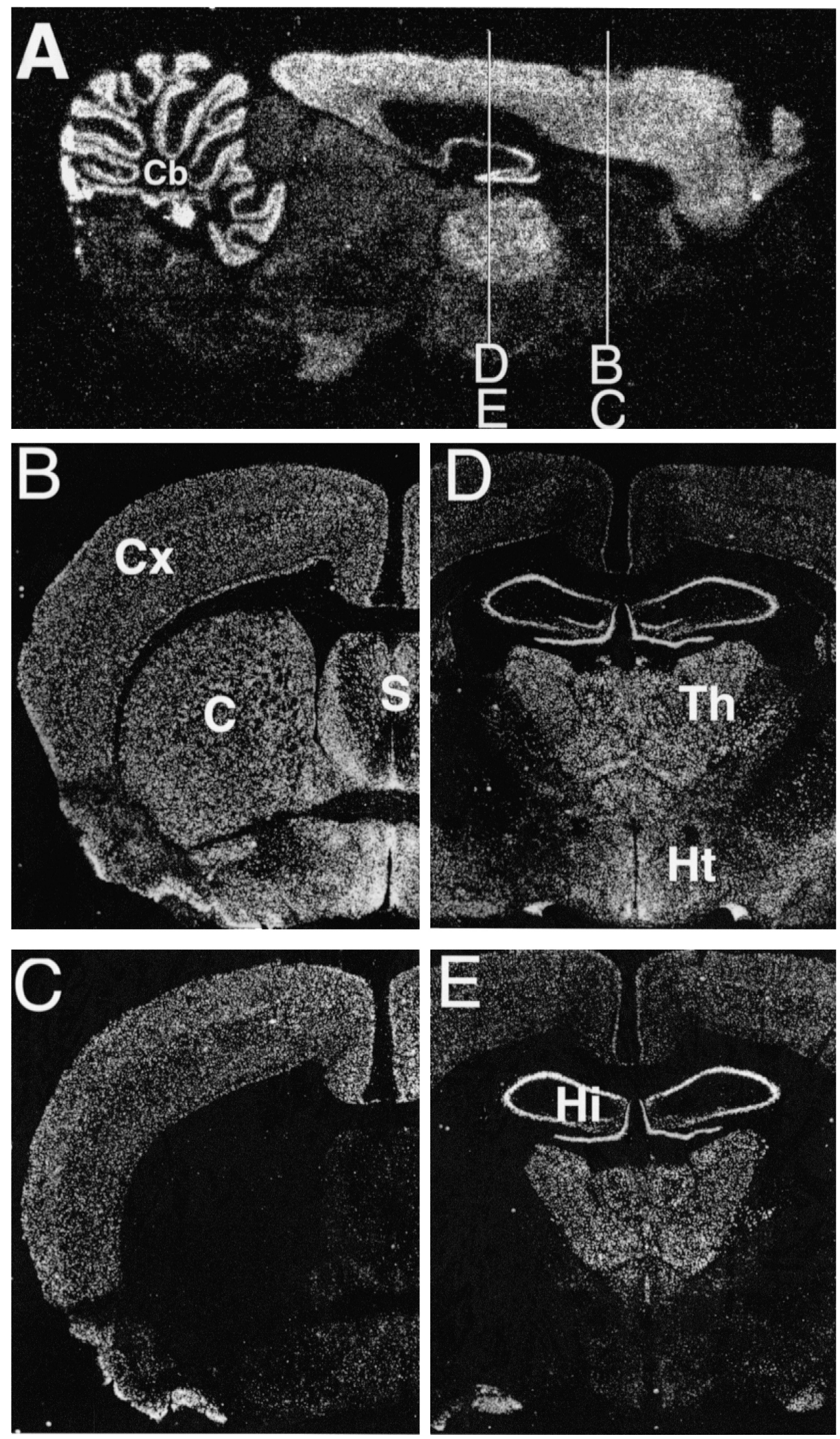

Fig. 5. Comparison of the distribution of gb2 and gb1 receptor mRNA in the rat brain by in situ hybridization histochemistry. (A) shows an autoradiographic image of a parasagittal rat brain section hybridized with the rat gb2 probe. The perpendicular lines depict the levels at which $12 \mu \mathrm{m}$ thin coronal sections (B-E) are shown. (B) and (C), and (D) and (E) show the same levels (adjacent sections) hybridized with rat gb1 (B and D) and gb2 (C and E) receptor probes. Note the lack of grains over the caudate nucleus, septum and preoptic area in (C) as compared with (B), and the lack of grains over the hypothalamus in (E) as compared with (D). Abbreviations: $\mathrm{C}=$ caudate nucleus; $\mathrm{Cx}=$ cerebral cortex; $\mathrm{Hi}=$ hippocampus; $\mathrm{Hth}=$ hypothalamus; $\mathrm{PO}=$ preoptic area; $\mathrm{S}=$ septum; $\mathrm{Th}=$ thalamus. Scale $\mathrm{bar}=1 \mathrm{~mm}$. 

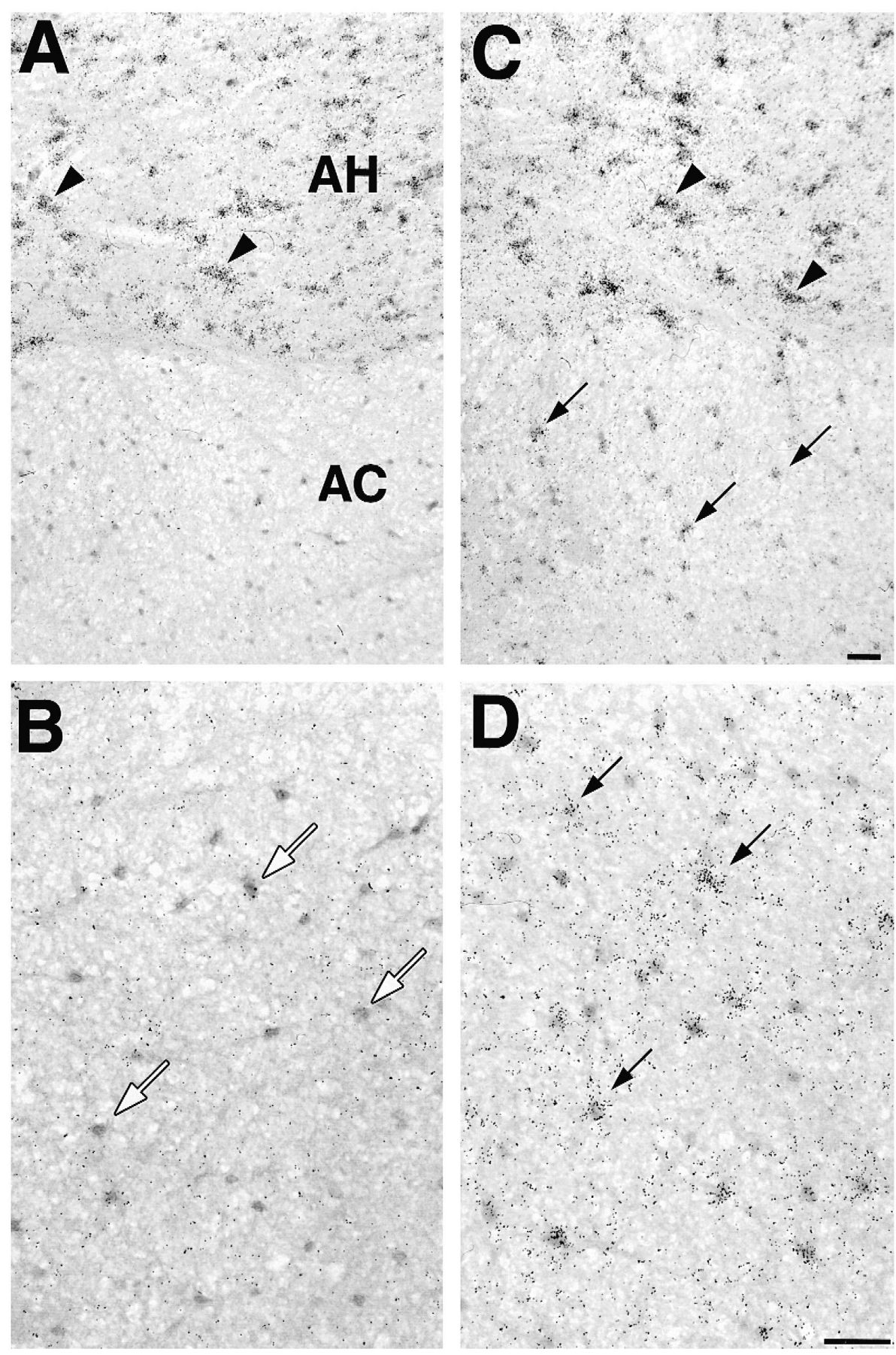

Fig. 6. Localization of gb2 and gb1 receptor mRNA in rat spinal cord. Gb2 (A and B) and gb1 (C and D) receptor mRNA in the anterior horn and anterior column of the spinal cord. Note specific hybridization of gb2 and gb1 probes to motorneurons in the anterior horn (A and C) and specific hybridization of the gb1 probe to glial cells in the anterior column at a higher magnification (D). Arrowheads denote neurons specifically hybridizing with the probes; white arrows denote nuclei of glial cells that do not hybridize with the gb2 probe; black arrows denote glia that specifically hybridize with the gb1 probe. $\mathrm{AC}=$ anterior column; $\mathrm{AH}=$ anterior horn. Scale bar $=25 \mu \mathrm{m}$.

Fig. 7. Colocalization of mRNA for $\mathrm{GABA}_{\mathrm{B}}$ receptor subtypes by in situ hybridization histochemistry in rat brain. Rat gb1 probe was digoxigenin-UTP labeled and developed using anti-digoxigenin HRP, the TSA amplification method and CY3-tyramide. Rat gb2 probe was labeled using ${ }^{35}$ S-UTP. The slides were emulsion-coated and autoradiography was developed after 4 weeks. (A-C) Cerebellum, (D-F) hippocampus, (G-I) cortex, and (J-L) vestibular ganglion. (A), (D), (G) and (J) show autoradiography with the gb2 receptor probe. Red cells in (B), (E), (H) and (K) express gb1 receptor mRNA in the same fields as shown in (A), (D), (G) and (J). (C), (F), (I) and (L) are overlays of images (A) and (B), (D) and (E), (G) and (H), and (J) and $(\mathrm{K})$, respectively. Arrows denote some of the double-labeled cells. Note the fibers of the eighth nerve passing through the middle of the image in (K). 

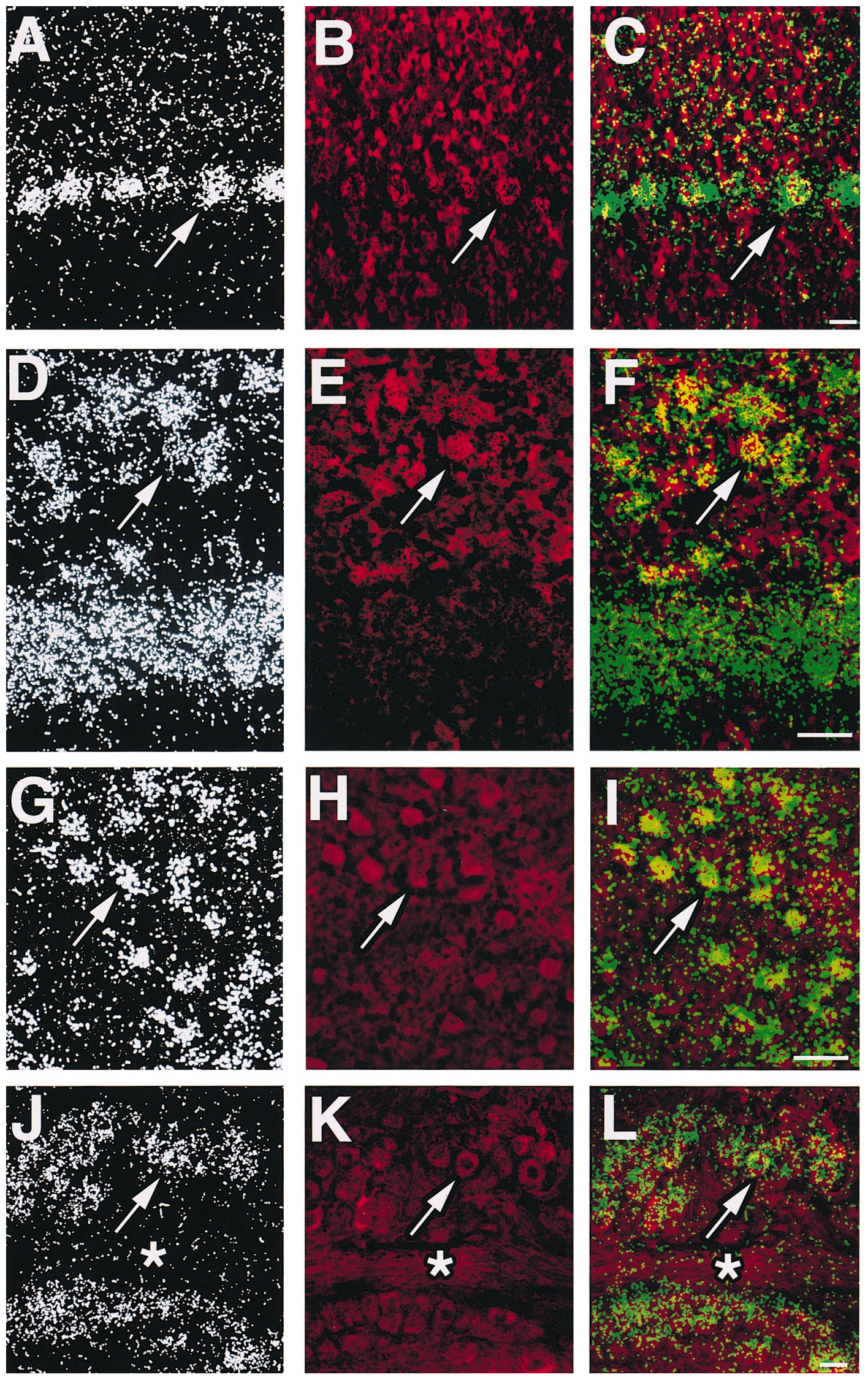
glia in white matter throughout the CNS including the corpus callosum (Fig. 5B). In the spinal cord gb1 and gb2 transcripts are abundant in neurons of the gray matter but only the gb1 probe hybridizes specifically to glial cells in the white matter (Fig. 6). Gb1 receptor message was detected in glial cells throughout the brain in addition to glial cells in white matter (data not shown). While we have been unable to detect hybridization to rgb2 mRNA in glia under the conditions used, more detailed studies of rgb2 mRNA expression and protein localization at the cellular level are necessary before we can rule out this possibility.

Since many brain regions showed overlapping expression patterns for $\mathrm{gb} 2$ and gb1 receptor message, colocalization studies for the two receptors were performed to determine if message for the two receptors is found in the same cells in these regions. Fig. 7 shows colocalization of gb1 and gb2 receptor message in the cerebellum (Fig. 7A-C), hippocampus (Fig. 7D-F), cortex (Fig. 7G-I) and vestibular ganglion (Fig. $7 \mathrm{~J}-\mathrm{L}$ ), four of the many rat brain regions examined. Neurons in the circumventricular organs including organum vasculosum laminae terminalis (OVLT), subfornical organ, median eminence, subcommissural organ, and area postrema express both receptor mRNAs at equally high levels (data not shown). In addition, the ventricular ependyma of the third ventricle in the hypothalamus expresses high levels of both receptor mRNAs (data not shown). In all other major brain regions tested where both mRNAs were found, the gb2 and gb1 receptor mRNA is colocalized with $\geq 95 \%$ of gb2 expressing cells also expressing gb1.

\section{Discussion}

There are several clinical situations in which $\mathrm{GABA}_{\mathrm{B}}$ receptors may prove to be potential sites for therapeutic intervention. Disrupted GABAergic neurotransmission has been implicated in a number of neurological and psychiatric disorders, including epilepsy, schizophrenia, and affective disorders. Due to the potential therapeutic value of $\mathrm{GABA}_{\mathrm{B}}$ receptors, it is important to identify the molecular structures of $\mathrm{GABA}_{\mathrm{B}}$ receptors and understand how they function. Recent work by Kaupmann et al. [14] revealed the first primary sequence information for members of this receptor family. Binding experiments with membranes expressing the cloned gb1 receptor clearly showed a rank order of potency for $\mathrm{GABA}_{\mathrm{B}}$ receptor-specific compounds in accordance with those observed for native $\mathrm{GABA}_{\mathrm{B}}$ receptors. However, attempts to show consistent and robust $\mathrm{GABA}_{\mathrm{B}}$ receptor function in any in vitro system tested were unsuccessful $[14,16]$ most likely due to inappropriate plasma membrane targeting [10]. In this manuscript we describe the identification and isolation of human and rat homologues of a novel receptor, gb2, with $35 \%$ amino acid sequence homology to the gb1 receptors identified by Kaupmann et al. [14]. Like the gb1 receptors, we were unable to detect $\mathrm{gb} 2$ receptor function in the various assays tested, yet unlike the gb1 receptors, no detectable binding could be observed with $\mathrm{GABA}_{\mathrm{B}}$ receptor agonists or antagonists in membranes expressing the cloned gb2 receptor. However, we and others have shown that coexpression of $\mathrm{gb} 1$ and $\mathrm{gb} 2$ receptors together in many different in vitro expression systems yields functional $\mathrm{GABA}_{\mathrm{B}}$ receptors $[12,15,19,23,29]$. In addition, we have shown that coexpression of gb1 and gb2 receptors results in the formation of heterodimers that are thought to represent the functional form of $\mathrm{GABA}_{\mathrm{B}}$ receptor.

In performing a detailed analysis of the CNS distribution of $\mathrm{gb} 2$ receptor message in rat brain by in situ hybridization histochemistry we observed that there are many regions where gb1 and gb2 receptor message overlap including the cortex, hippocampus, thalamus and many hindbrain areas including the cerebellum and ganglia. As shown in Fig. 7, at the cellular level, the vast majority of cells expressing gb2 receptor message in the rat brain also express gb1 receptor message. Kaupmann et al. [15] have gone a step further in Purkinje cells only demonstrating that both $\mathrm{gb} 1$ and $\mathrm{gb} 2$ receptor message and proteins colocalize. These data do not prove that native $\mathrm{GABA}_{\mathrm{B}}$ receptors in these cells are $\mathrm{gb} 1 / \mathrm{gb} 2$ heterodimers, yet these findings strongly suggest that native $\mathrm{GABA}_{\mathrm{B}}$ receptor function in these cells involves both $\mathrm{gb} 1$ and $\mathrm{gb} 2$ receptors.

In contrast to the robust and ubiquitous expression of gb1 receptor mRNAs in rat brain, gb2 receptor message is somewhat more discretely localized. Levels of gb2 receptor message in caudate/putamen, hypothalamus, septum, preoptic area, and substantia nigra are low to undetectable (Figs. 4 and 5), whereas gb1 receptor message is present at moderate to high levels. Likewise, gb2 receptor message is undetectable in glial cells of white matter throughout the rat brain and spinal cord. Expression of gb1 receptor message, however, is detected in glial cells of all white matter and in glia throughout many areas of the brain. These data indicate that gb2 message is found exclusively in neurons.

The previously described binding of GABA to rat brain in the presence of the $\mathrm{GABA}_{\mathrm{A}}$ receptor agonist isoguvacine $[5,8]$ parallels the observed distribution of $\mathrm{gb} 2$ receptor message presented in Figs. 4 and 5. GABA binding in regions including cortex, thalamus, and cerebellum is relatively robust as is expression of both gb1 and gb2 receptor message. Certain regions including the septal area, caudate/putamen, hypothalamus and brainstem, with the exception of the interpeduncular nucleus exhibited relatively low levels of GABA binding [5,8]. In this study we have shown that these same regions that exhibit poor GABA binding express low to undetectable levels of gb2 receptor message. Regions where robust GABA binding overlap with robust expression of both gb1 and gb2 receptor message most likely represent regions where cells are coexpressing a functional $\mathrm{GABA}_{\mathrm{B}}$ receptor in the form of 
a gb1/gb2 heterodimer. Agreement of the gb1/gb2 message expression levels with the levels of GABA binding in rat brain lends further support to the hypothesis that functional native $\mathrm{GABA}_{\mathrm{B}}$ receptors in many major brain regions are composed of $\mathrm{gb} 1 / \mathrm{gb} 2$ heteromers. However, $\mathrm{gb} 1 / \mathrm{gb} 2$ receptor heteromers may not account for $\mathrm{GABA}_{\mathrm{B}}$ receptor function in regions where gb1 receptor message is expressed with little or no detectable gb2 receptor message. The composition of functional $\mathrm{GABA}_{\mathrm{B}}$ receptors in these regions remains to be determined.

There are several possible reasons why one may find functional $\mathrm{GABA}_{\mathrm{B}}$ receptors in regions where expression of gb1 receptor message is robust and gb2 receptor message is relatively low. Cells exhibiting low levels of gb2 receptor message may express the appropriate cellular components necessary for the expression of functional homomultimeric gb1 receptors at the cell surface. Evidence for the existence of homomultimeric receptors comes from recent reports which have shown that GPCRs, including the parathyroid calcium-sensing and metabotropic glutamate receptors, form homomultimeric structures which may be important for function [1,27]. At least two groups have shown that expression of gb1 using various cell culture systems results in accumulation of a major portion of the expressed protein in intracellular compartments $[10,29]$. Coexpression of gb1 with gb2 results in the targeting of gb1 to the cell surface in the form of a functional $\mathrm{gb} 1 / \mathrm{gb} 2$ heteromer [29]. In addition, binding assays done with membranes from cells expressing gb1/gb2 heteromers result in a 10- to 100-fold shift to the left in the apparent affinities for agonists when compared with assays done with membranes expressing gb1 only [15,29]. These data suggest that the formation of a homomultimeric $\mathrm{gb} 1$ receptor and targeting of such a receptor to the cell surface may involve accessory proteins that are not expressed by the cells used for in vitro study of this receptor. Recent work has shown that accessory proteins termed receptoractivity modifying proteins (RAMPs) have a dramatic affect on the cell surface expression and pharmacology of the GPCR calcitonin-receptor-like receptor [21]. Therefore, it is possible that similar proteins are involved with the expression and targeting of functional $\mathrm{GABA}_{\mathrm{B}}$ receptors in cells expressing gb1 receptor message alone. Another recently identified family of proteins, RGS or regulator of $\mathrm{G}$ protein signaling molecules, have been shown to modify metabotropic glutamate receptor-mediated ion channel modulation [13]. Therefore, it is possible that our inability to observe gb1 receptor function in in vitro systems is due to the presence or absence of accessory proteins such as RGS-like proteins.

Alternatively, regions where only gb1 mRNA is detected may express heteromeric $\mathrm{GABA}_{\mathrm{B}}$ receptors composed of gb1 and other as yet unidentified $\mathrm{GABA}_{\mathrm{B}}$ receptor subunits. Homology-based cloning strategies should reveal additional members of this $\mathrm{GABA}_{\mathrm{B}}$ receptor family if they exist. Given the extent and diversity of most receptor families, it would not be surprising to find additional $\mathrm{GABA}_{\mathrm{B}}$ receptor subunits.

Finally, gb2 receptor mRNA levels may be undetectable in particular brain regions due to highly specific gene regulation, whereby gb2 receptor message is only expressed after a particular cellular insult. In such a case, functional $\mathrm{GABA}_{\mathrm{B}}$ receptor heteromers would only be expressed when a cell needs the protection afforded by $\mathrm{GABA}_{\mathrm{B}}$ receptor activation.

While it is now well established that $\mathrm{gb} 1 / \mathrm{gb} 2$ heterodimers form in in vitro systems and exhibit the properties expected of a $\mathrm{GABA}_{\mathrm{B}}$ receptor, it is still unclear if these heteromers form in vivo and to what extent. This study provides the first extensive examination of the distribution of gb2 receptor message in the rat CNS. The significant overlap in gb1 and gb2 receptor message expression observed in the same cells in many brain regions suggests that $\mathrm{gb} 1 / \mathrm{gb} 2$ heterodimers account for the structure of functional $\mathrm{GABA}_{\mathrm{B}}$ receptors throughout much of the brain. However, detailed immunohistochemical analyses are needed to confirm the existence of gb1/gb2 heterodimers in vivo. Furthermore, much work needs to be done to determine the composition and functional properties of $\mathrm{GABA}_{\mathrm{B}}$ receptors in cells where gb1 receptor message is exclusively expressed.

\section{Acknowledgements}

J.A.C. was supported by a Young Investigator Award from the National Alliance for Research on Schizophrenia and Depression.

\section{References}

[1] M. Bai, S. Trivedi, E.M. Brown, Dimerization of the extracellular calcium-sensing receptor $(\mathrm{CaR})$ on the cell surface of CaR-transfected HEK293 cells, J. Biol. Chem. 273 (1998) 23605-23610.

[2] T.I. Bonner, N.J. Buckley, A.C. Young, M.R. Brann, Identification of a family of muscarinic acetylcholine receptor genes, Science 237 (1987) 527-532.

[3] N.G. Bowery, A.L. Hudson, $\gamma$-Aminobutyric acid reduces the evoked release of ${ }^{3} \mathrm{H}$-noradrenaline from sympathetic nerve terminals, Br. J. Pharmacol. 66 (1979) 108.

[4] N.G. Bowery, A. Doble, D.R. Hill, A.L. Hudson, J.S. Shaw, M.J. Turnbull, R. Warrington, Bicuculline-insensitive GABA receptors on peripheral autonomic nerve terminals, Eur. J. Pharmacol. 71 (1981) 53-70.

[5] N.G. Bowery, A.L. Hudson, G.W. Price, $\mathrm{GABA}_{A}$ and $\mathrm{GABA}_{\mathrm{B}}$ receptor site distribution in the rat central nervous system, Neuroscience 20 (1987) 365-383.

[6] N.G. Bowery, GABA ${ }_{B}$ receptor pharmacology, Annu. Rev. Pharmacol. Toxicol. 33 (1993) 109-147.

[7] D.J. Bradley, H.C. Towle, W.S. Young, Spatial and temporal expression of alpha- and beta-thyroid hormone receptor mRNAs, including the beta 2 -subtype, in the developing mammalian nervous system, J. Neurosci. 12 (1992) 2288-2302.

[8] D.C.M. Chu, R.L. Albin, A.B. Young, J.B. Penney, Distribution and kinetics of $\mathrm{GABA}_{\mathrm{B}}$ binding sites in rat central nervous system: a 
quantitative autoradiographic study, Neuroscience 34 (1990) 341357.

[9] M.G. Claros, S. Brunak, G. von Heijne, Prediction of N-terminal protein sorting signals, Curr. Opin. Struct. Biol. 7 (1997) 394-398.

[10] A. Couve, A.K. Filippov, C.N. Connolly, B. Bettler, D.A. Brown, S.J. Moss, Intracellular retention of recombinant $\mathrm{GABA}_{\mathrm{B}}$ receptors, J. Biol. Chem. 273 (1998) 26361-26367.

[11] D.R. Hill, N.G. Bowery, ${ }^{3}$ H-Baclofen and ${ }^{3}$ H-GABA bind to bicuculline-insensitive GABA $_{B}$ sites in rat brain, Nature 290 (1981) $149-152$.

[12] K.A. Jones, B. Borowsky, J.A. Tamm, D.A. Craig, M.M. Durkin, M. Dai, W.-J. Yao, M. Johnson, C. Gunwaldsen, L.-Y. Huang, C. Tang, Q. Shen, J.A. Salon, K. Morse, T. Laz, K.E. Smith, D. Nagarathnam, S.A. Noble, T.A. Branchek, C. Gerald, GABA B receptors function as a heteromeric assembly of the subunits $\mathrm{GABA}_{\mathrm{B}} \mathrm{R} 1$ and GABA $\mathrm{B}$ R2, Nature 396 (1998) 674-678.

[13] P.J. Kammermeier, S.R. Ikeda, Expression of RGS2 alters the coupling of metabotropic glutamate receptor 1a to M-type $\mathrm{K}+$ and N-type Ca + channels, Neuron 22 (1999) 819-829.

[14] K. Kaupmann, K. Huggel, J. Heid, P.J. Flor, S. Bischoff, S.J. Mickel, G. McMaster, C. Angst, H. Bittiger, W. Froestl, B. Bettler, Expression cloning of $\mathrm{GABA}_{\mathrm{B}}$ receptors uncovers similarity to metabotropic glutamate receptors, Nature 386 (1997) 239-246.

[15] K. Kaupmann, B. Malitschek, V. Schuler, J. Heid, W. Froestl, P. Beck, J. Mosbacher, S. Bischoff, A. Kulik, R. Shigemoto, A. Karschin, B. Bettler, $\mathrm{GABA}_{\mathrm{B}}$-receptor subtypes assemble into functional heteromeric complexes, Nature 396 (1998) 683-687.

[16] K. Kaupmann, V. Schuler, J. Mosbacher, S. Bischoff, H. Bittiger, J. Heid, W. Froestl, S. Leonhard, T. Pfaff, A. Karschin, B. Bettler, Human g-aminobutyric acid type B receptors are differentially expressed and regulate inwardly rectifying $\mathrm{K}^{+}$channels, Proc. Natl. Acad. Sci. U. S. A. 95 (1998) 14991-14996.

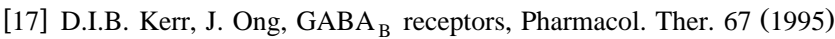
$187-246$.

[18] K. Krempels, B. Hunyady, A.M. O'Carroll, É. Mezey, Distribution of somatostatin receptor messenger RNAs in the rat gastrointestinal tract, Gastroenterology 112 (1997) 1948-1960.
[19] R. Kuner, G. Köhr, S. Grünewald, G. Eisenhardt, A. Bach, H.-C. Kornau, Role of heteromer formation in $\mathrm{GABA}_{\mathrm{B}}$ receptor function, Science 283 (1999) 74-77.

[20] J. Kyte, R.F. Doolittle, A simple method for displaying the hydropathic character of a protein, J. Mol. Biol. 157 (1982) 105-132.

[21] L.M. McLatchie, N.J. Fraser, M.J. Main, A. Wise, J. Brown, N. Thompson, R. Solari, M.G. Lee, S.M. Foord, RAMPs regulate the transport and ligand specificity of the calcitonin-receptor-like receptor, Nature 393 (1998) 333-339.

[22] U. Misgeld, M. Bijak, W. Jarolimek, A physiological role for $\mathrm{GABA}_{\mathrm{B}}$ receptors and the effects of baclofen in the mammalian central nervous system, Prog. Neurobiol. 46 (1995) 423-462.

[23] G.Y.K. Ng, J. Clark, N. Coulombe, N. Ethier, T.E. Hebert, R. Sullivan, S. Kargman, A. Chateauneuf, N. Tsukamoto, T. McDonald, P. Whiting, É. Mezey, M.P. Johnson, Q. Liu, L.F. Kolakowski Jr., J.F. Evans, T.I. Bonner, G.B.P. O'Neill, Identification of a $\mathrm{GABAB}$ receptor subunit, gb2, required for functional $\mathrm{GABA}_{\mathrm{B}}$ receptor activity, J. Biol. Chem. 274 (1999) 7607-7610.

[24] H. Nielsen, J. Engelbrecht, S. Brunak, G. von Heijne, A neural network method for identification of prokaryotic and eukaryotic signal peptides and prediction of their cleavage sites, Int. J. Neural Syst. 8 (1997) 581-599.

[25] G. Paxinos, C. Watson, The Rat Brain in Stereotaxic Coordinates, Academic Press, San Diego, 1997.

[26] J.-P. Pin, R. Duvoisin, Review: Neurotransmitter receptors: I. The metabotropic glutamate receptors: structure and functions, Neuropharmacology 34 (1995) 1-26.

[27] C. Romano, W.-L. Yang, K.L. O'Malley, Metabotropic glutamate receptor 5 is a disulfide-linked dimer, J. Biol. Chem. 271 (1996) 28612-28616.

[28] J. Sambrook, E.F. Fritsch, T. Maniatis, Molecular Cloning, Cold Spring Harbor Laboratory Press, Cold Spring Harbor, 1989.

[29] J.H. White, A. Wise, M.J. Main, A. Green, N.J. Fraser, G.H. Disney, A.A. Barnes, P. Emson, S.M. Foord, F.H. Marshall, Heterodimerization is required for the formation of a functional $\mathrm{GABA}_{\mathrm{B}}$ receptor, Nature 396 (1998) 679-682. 